\title{
A novel method for transmitting southern rice black-streaked dwarf virus to rice without insect vector
}

\author{
Lu Yu, Jing Shi, Lianlian Cao, Guoping Zhang, Wenli Wang, Deyu Hu and Baoan Song*
}

\begin{abstract}
Background: Southern rice black-streaked dwarf virus (SRBSDV) has spread from the south of China to the north of Vietnam in the past few years, and has severely influenced rice production. However, previous study of traditional SRBSDV transmission method by the natural virus vector, the white-backed planthopper (WBPH, Sogatella furcifera), in the laboratory, researchers are frequently confronted with lack of enough viral samples due to the limited life span of infected vectors and rice plants and low virus acquisition and inoculation efficiency by the vector. Meanwhile, traditional mechanical inoculation of virus only apply to dicotyledon because of the higher content of lignin in the leaves of the monocot. Therefore, establishing an efficient and persistent-transmitting model, with a shorter virus transmission time and a higher virus transmission efficiency, for screening novel anti-SRBSDV drugs is an urgent need.

Methods: In this study, we firstly reported a novel method for transmitting SRBSDV in rice using the bud-cutting method. The transmission efficiency of SRBSDV in rice was investigated via the polymerase chain reaction (PCR) method and the replication of SRBSDV in rice was also investigated via the proteomics analysis.

Results: Rice infected with SRBSDV using the bud-cutting method exhibited similar symptoms to those infected by the WBPH, and the transmission efficiency $(>80.00 \%)$, which was determined using the PCR method, and the virus transmission time (30 $\mathrm{min}$ ) were superior to those achieved that transmitted by the WBPH. Proteomics analysis confirmed that SRBSDV P1, P2, P3, P4, P5-1, P5-2, P6, P8, P9-1, P9-2, and P10 proteins were present in infected rice seedlings infected via the bud-cutting method.

Conclusion: The results showed that SRBSDV could be successfully transmitted via the bud-cutting method and plants infected SRBSDV exhibited the symptoms were similar to those transmitted by the WBPH. Therefore, the use of the bud-cutting method to generate a cheap, efficient, reliable supply of SRBSDV-infected rice seedlings should aid the development of disease control strategies. Meanwhile, this method also could provide a new idea for the other virus transmission in monocot.
\end{abstract}

Keywords: SRBSDV, Bud-cutting method, Transmission efficiency, PCR, Proteomics

\footnotetext{
* Correspondence: +86-0851-83620521songbaoan22@yahoo.com

State Key Laboratory Breeding Base of Green Pesticide and Agricultural

Bioengineering, Key Laboratory of Green Pesticide and Agricultural

Bioengineering, Ministry of Education, Guizhou University, Guiyang 550025,

China
}

(c) The Author(s). 2017 Open Access This article is distributed under the terms of the Creative Commons Attribution 4.0 International License (http://creativecommons.org/licenses/by/4.0/), which permits unrestricted use, distribution, and reproduction in any medium, provided you give appropriate credit to the original author(s) and the source, provide a link to the Creative Commons license, and indicate if changes were made. The Creative Commons Public Domain Dedication waiver (http://creativecommons.org/publicdomain/zero/1.0/) applies to the data made available in this article, unless otherwise stated. 


\section{Background}

Belonging to the genus Fijivirus (family Reoviridae), southern rice black-streaked dwarf virus (SRBSDV) is the causal agent of a rice dwarfing disease that was first discovered and named in China. SRBSDV was recognized as a new species in 2008 [1]. SRBSDV has spread from the south of China to the north of Vietnam in the last few years, and has severely affected rice production [2-4]. In 2009, SRBSDV infected nearly 741,000 acres of rice and rice farms covering 100,000 acres in total reported crop failure, which was a significant loss in China [5]. Meanwhile, in 2010, about 2.97 million acres in China were effected by SRBSDV [6]. To try to combat this disease, researchers are actively screening for effective anti-SRBSDV drugs and investigating preventive measures for controlling SRBSDV. However, the lack of sufficient viral samples due to the limited life span of infected vectors and rice plants and the vector's low virus acquisition and inoculation rate is hampering this research effort. To generate viral samples, researchers have to successively collect rice plants and white-backed planthopper (WBPH, Sogatella furcifera) from paddy fields infected with SRBSDV, which is time-consuming, expensive and, most importantly, this method does not ensure a timely supply of SRBSDV-infected vectors or infected rice plants $[7,8]$. Therefore, there is an urgent need to establish an efficient and persistent-transmitting model, with a shorter virus transmission time and a higher virus transmission efficiency, to screen novel anti-SRBSDV drugs. Furthermore, SRBSDV not only infects rice but also a number of other graminaceous plants, such as Echinochloa crusgalli L., Zea mays L., Paspalum distichum L., and Alopecurus aequalis Sobol., and cyperaceous plants, such as Juncellus serotinus (Rottb.) C. B. Clarke and Cyperus difformis L. [9].

In the laboratory, SRBSDV is traditionally transmitted by the WBPH, a long-distance migratory pest, via the method of simulating the natural environment $[2,10]$. When infected with SRBSDV, the rice symptoms often develops stunted stems, dark green and twisted leaves, white waxy swellings on the leaf veins and so on [11]. However, the symptoms are not obvious at the beginning of the infection, so several methods, such as polymerase chain reaction (PCR), enzyme-linked immunosorbent assay (ELISA), and reverse transcription loop-mediated isothermal amplification assay, have been applied to diagnose SRBSDV infection. Meanwhile, PCR denaturing gradient gel electrophoresis (PCR-DGGE) has been used to measure at different temperatures, how SRBSDV's transmission efficiency and their characteristics among various host plants change [8, 12-14]. In addition, our group has previously reported a novel method relied on rice suspension cells so that we can test antiviral compounds against SRBSDV; the transmission efficiency of
SRBSDV was determined using the real time quantitative PCR (RT-qPCR) [15].

In this study, we firstly reported a novel method for transmitting SRBSDV in rice using the bud-cutting method to generate a reliable supply of rice infected with SRBSDV for screening novel anti-SRBSDV drugs. The results showed that SRBSDV could be successfully transmitted via the bud-cutting method and plants infected SRBSDV exhibited the symptoms were similar to those transmitted by the WBPH. Meanwhile, the transmission efficiency of SRBSDV in rice was investigated via the PCR method and the results demonstrated that the budcutting method was an efficient persistent-transmitting method with a shorter virus transmission time $(30 \mathrm{~min})$ and a higher virus transmission efficiency (> 80.00\%). Moreover, proteomics analysis demonstrated that SRBSDV could also replicate in rice in the whole growth period. To our knowledge, it is the first report on the SRBSDV transmission in rice using the bud-cutting method.

\section{Methods \\ Material preparation}

Rice plants, after elongation stage that had obvious tumor-like protrusion symptoms and checked the SRBSDV via the RT-qPCR method, studied herein were acquired in Libo city, Guizhou province, southern China in the autumn of 2015. The rice samples were frozen in liquid nitrogen and ground to obtain a fine powder. Then, the powder (approximately $30 \mathrm{~g}$ ) was soaked in $100 \mathrm{~mL} 0.2 \mathrm{M}$ PBS buffer (pH 5.8; consists of $0.2 \mathrm{M}$ PBS, $10 \mathrm{mM}$ 2-( $N$-morpholino)ethanesulfonic acid, and $100 \mu \mathrm{M}$ acetosyringone) for $30 \mathrm{~min}$ and filtered with gauze to obtain the crude SRBSDV extraction buffer.

\section{SRBSDV transmission}

Rice seeds (Oryza sativa L., Fengyouxiangzhan) were soaked in water for approximately 2 days at room temperature. After breaking the seed coat, the seeds were pre-germinated at $40{ }^{\circ} \mathrm{C}$ for approximately 3 days in an illuminated incubator until a bud of approximately $1.0 \mathrm{~cm}$ in length had developed. The bud was cut at a $45^{\circ}$ angle approximately $0.5 \mathrm{~cm}$ from the base of the bud (Fig. 1). Then, the treated seedlings were soaked in the crude SRBSDV extract for $30 \mathrm{~min}$ to inoculate the seedlings with SRBSDV before incubating the seedlings in the dark at $28-30{ }^{\circ} \mathrm{C}$ for 3 days. The rice seedlings were then planted in a soil matrix and incubated for 25 days at a relative humidity of $50 \%$, a temperature of $28-30{ }^{\circ} \mathrm{C}$, and light/dark cycles of $14 / 10 \mathrm{~h}$. Then, samples were collected from the rice plants and maintained at $-80{ }^{\circ} \mathrm{C}$ until needed for determining the SRBSDV transmission efficiency and characterizing the SRBSDV proteins. Finally, the rice seedlings were planted out in the experimental fields to observe any symptoms of disease. 


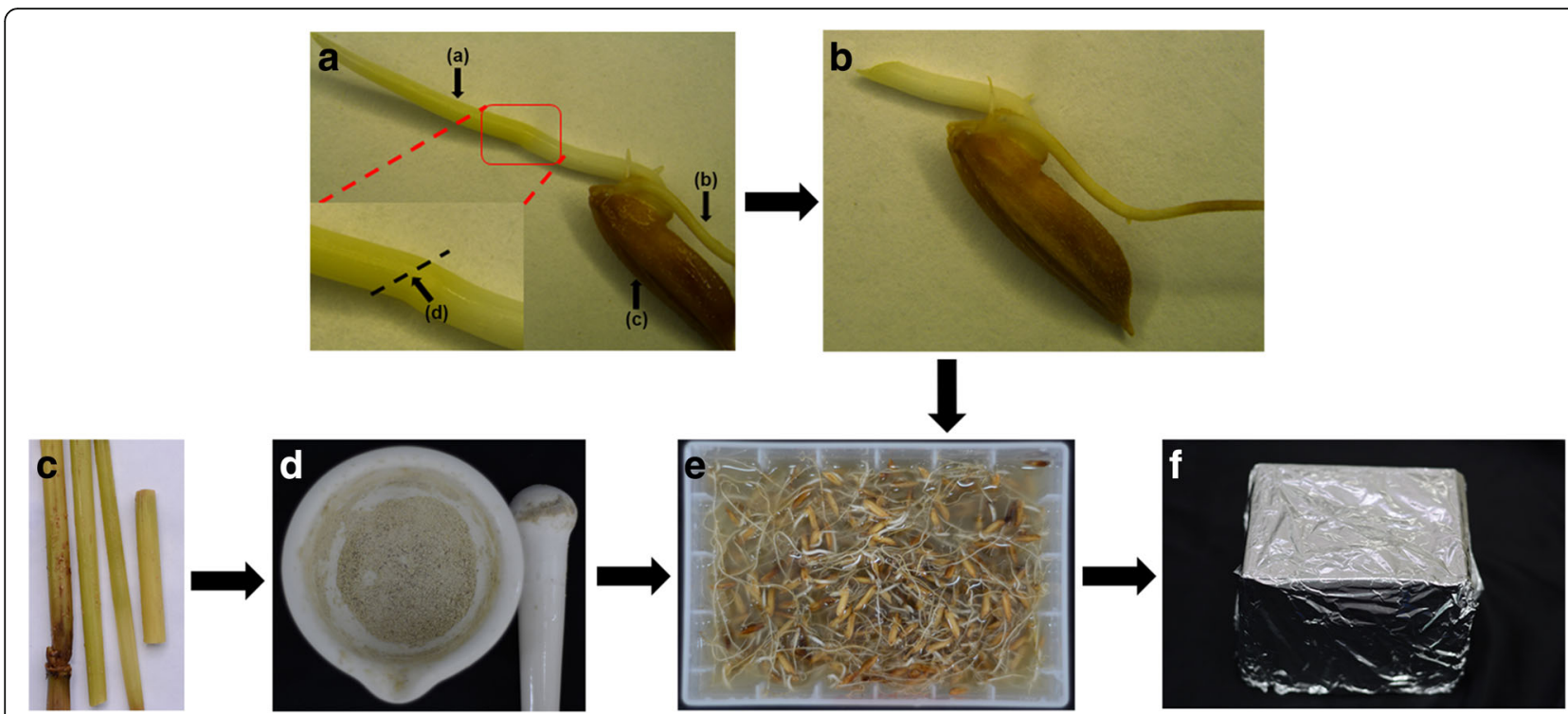

Fig. 1 The SRBSDV transmission process using the bud-cutting method. a The germinated rice seed. (a) The germ, (b) The radicle, (c) The cotyledon, (d) The position (a cyclic structure) for cutting bud at a $45^{\circ}$ angle approximately $0.5 \mathrm{~cm}$ from the base of the bud. $\mathbf{b}$ The bud-cutting rice seed. $\mathbf{c}$ The rice stems which were had obvious tumor-like protrusion symptoms. $\mathbf{d}$ The rice stems were frozen in liquid nitrogen and ground to obtain a fine powder. $\mathbf{e}$ The treated seedlings were soaked in the crude SRBSDV extract for 30 min to inoculate the seedlings with SRBSDV. $\mathbf{f}$ The seedlings were incubated in the dark at $28-30{ }^{\circ} \mathrm{C}$ for 3 days

\section{RNA extraction, CDNA synthesis, and PCR analysis}

According to the instructions of the manufacturer's instructions, total RNAs were extract from the samples via the use of a Trizol reagent kit (TaKaRa, Dalian, China). The purity and concentration of RNA was determined with an ultraviolet spectrophotometer (ACTGene, Piscataway, NJ, USA) and total RNA purity was estimated by calculating $\mathrm{OD}_{260} / \mathrm{OD}_{280}$. And the concentration of total RNA was calculated according to the dilution ratio and the value of $\mathrm{OD}_{260}$.

cDNAs were also synthesized using TaKaRa's cDNA synthesis kit. Random primers $(0.5 \mu \mathrm{L})$ and total RNA (3000 ng/ $\mu \mathrm{L}, 1 \mu \mathrm{L}$ ) were added to $\mathrm{H}_{2} \mathrm{O}(4.75 \mu \mathrm{L})$ and heated for an hour at $42{ }^{\circ} \mathrm{C}$ and then $15 \mathrm{~min}$ at $70{ }^{\circ} \mathrm{C}$. Then, the solution was rapidly placed on ice to cool for $2 \mathrm{~min}$. After that, $2 \mu \mathrm{L}$ of $5 \times$ Moloney murine leukemia virus (M-MLV) buffer, $500 \mathrm{~nL}$ of $10 \mathrm{mM}$ dNTP, $250 \mathrm{~nL}$ of RNase Inhibitor (RRI), and $500 \mathrm{~nL}$ of M-MLV Reverse Transcriptase were added to the above solution. Finally, in the thermocycler, the PCR amplification conditions were set as: $10 \mathrm{~min}$ at $30{ }^{\circ} \mathrm{C}$, an hour at $42{ }^{\circ} \mathrm{C}$, and 15 min at $70{ }^{\circ} \mathrm{C}$.

A final reaction volume of $20 \mu \mathrm{L}$, consists of $2 \mu \mathrm{L}$ of $10 \times$ PCR buffer, $1.6 \mu \mathrm{L}$ of dNTP $(2.5 \mathrm{mM}), 1.6 \mu \mathrm{L}$ of $\mathrm{MgCl}_{2}(2.5 \mathrm{mM}), 200 \mathrm{~nL}$ of rTaq, $800 \mathrm{~nL}$ of each $\mathrm{S} 7-1$ primer (10 mmol; forward primer, $5^{\prime}$-GGAATTCATGG ATAGACCTGCTCGA-3'; reverse primer, 5'-CGGGA TCCTTAAGATGATGGAGATTC-3') or S9-1 primer (10 mmol; forward primer, 5'-GGAATTCATGGCAG ACCAAGAGCGT-3'; reverse primer, 5'-CGGGATCC
TCAAACGTCCAATTTAAG-3'), which were designed using the Primer Premier 5.0 software (PREMIER Biosoft International, USA) according the reported complete genome sequence of SRBSDV [16], $2 \mu \mathrm{L}$ of cDNA, and $11 \mu \mathrm{L}$ of $\mathrm{H}_{2} \mathrm{O}$, was produced for PCR amplifications. The amplification conditions were set at $94{ }^{\circ} \mathrm{C}$ for $120 \mathrm{~s}$ and followed by 35 cycles of $30 \mathrm{~s}$ at $94{ }^{\circ} \mathrm{C}, 30 \mathrm{~s}$ at $58{ }^{\circ} \mathrm{C}$, and $70 \mathrm{~s}$ at $72{ }^{\circ} \mathrm{C}$, the next stage was extension at $72{ }^{\circ} \mathrm{C}$ and $12{ }^{\circ} \mathrm{C}$ for $10 \mathrm{~min}$, respectively, to realize a dissociation curve. The amplicons were sequenced at Sangon Corporation (Shanghai, China) and the results were compared with the known sequences deposited in the National Center for Biotechnology Information (NCBI, https://www.ncbi.nlm.nih.gov/) database using the Standard Nucleotide BLAST program.

After PCR analysis, the whole PCR reaction product was electrophoresed for $15 \mathrm{~min}$ on a $1.5 \%$ agarose gel. The transmission efficiency was calculated using the PCR results. The experiment was replicated three times.

\section{Protein extraction, mass spectrometry, and protein identification}

The protein extraction procedure was based on the phenol extraction method $[17,18]$. First, each pooled sample (approximately $1.5 \mathrm{~g}$ ) was frozen in situation filled with liquid nitrogen. Then they were ground into fine powder. $5 \mathrm{~mL}$ of protein extraction buffer of ice-cold temperature, which consists of $0.5 \mathrm{M}$ Tris- $\mathrm{HCl}(\mathrm{pH}$ 7.5), $0.7 \mathrm{M}$ sucrose, $0.1 \mathrm{M}$ $\mathrm{KCl}, 50 \mathrm{mM}$ EDTA, and $40 \mathrm{mM}$ dithiothreitol (DTT), was provided for suspending at room temperature for $15 \mathrm{~min}$. 
Add $5 \mathrm{~mL}$ of Tris-phenol to the suspension before shaking for $30 \mathrm{~min}$ and then centrifuging the suspension at $8000 \mathrm{~g}$ at $4{ }^{\circ} \mathrm{C}$ for $5 \mathrm{~min}$. Collect the upper phenolic phase and add equal extraction buffer to the supernatant. Then, add 4 volumes of $0.1 \mathrm{M}$ ammonium acetate dissolved in methanol to the supernatant before leaving it overnight at $-20{ }^{\circ} \mathrm{C}$ for the aim of protein precipitation. Next, discard the supernatant after centrifugation $8000 \mathrm{~g}$ at $4{ }^{\circ} \mathrm{C}$ for $10 \mathrm{~min}$, and then washed the pellet three times with acetone at $4{ }^{\circ} \mathrm{C}$. Finally, the pellet was dried in a vacuum drier for $2 \mathrm{~h}$ before solubilizing in $100 \mu \mathrm{L}$ of the rehydration solution $(8 \mathrm{M}(w / v)$ urea, $0.1 \mathrm{M}(w / v)$ Tris, $10 \mathrm{mM}$ DTT). Moreover, the protein concentration was measured using the Bradford method [19].

Through the use of a LC-MS/MS system, the total peptides from the proteins extracted from rice were measured [20]. A mass spectrometer (5600 Triple TOF MS) coupled to a Nano-Liquid Chromatogram (Eksigent, Dublin, CA) was used to perform all the analytics. First, $8 \mu \mathrm{L}$ of peptides $(1 \mu \mathrm{g} / \mu \mathrm{L})$ were injected automatically into a six-port valve and desalted for $10 \mathrm{~min}$ by applying a ChromXP Trap column (Nano LC TRAP Column) with the speed of $2 \mu \mathrm{L} /$ min. Second, the retained peptides were separated via a gradient elution mode using an analytical column-Nano LC $\mathrm{C}_{18}$ reversed-phase column $\left(3 \mathrm{C}_{18} \mathrm{CL}, 75 \mu \mathrm{m} \times 15 \mathrm{~cm}\right)$ at the speed of $300 \mathrm{~nL} / \mathrm{min}$, with $95 \%$ solvent $\mathrm{B}$ and $95 \%$ solvent A. The former consists of $95 \%$ acetonitrile (ACN), $5 \%$ HPLC grade water and $0.1 \% v / v$ formic acid (FA), while the latter consists of $5 \% \mathrm{ACN}, 95 \%$ HPLC grade water and $0.1 \% v / \mathrm{v}$ FA. Third, Analyst ${ }^{\circ}$ Software (TF 1.6) was used to operate the 5600 Triple TOF MS and enable to switch between TOF-MS and Product Ion acquisition automatically. Ultimately, the data were collected after selecting a range of $300-1600 \mathrm{~m} / \mathrm{z}$. In addition, a $\beta$-galactosidase digest standard was used to recalibrate the mass spectrometer when the flow path run of each sample was completed and a high voltage of $2.3 \mathrm{kV}$ was applied for stable spray operation. The use of Analyst ${ }^{\circ}$ Software (TF 1.6; Foster City, CA, USA) could control the LC pump, the automatic mass spectra acquisitions and mass spectrometer.

In this study, raw data from shotgun data acquisition (Wiff. files) were analyzed and identified through the use of Protein Pilot 4.5 software. The UniProt (release 2016-12) database, restricted to SRBSDV, was used to search the MS/MS spectra using the Andromeda search engine [21]. The sequences of all proteins were retrieved using their accession numbers in FASTA format from Uniprot database (http://www.uniprot.org/).

\section{Results}

\section{Symptoms}

Plants infected at the early seedling stage exhibit dwarfism (less than half the normal height) and stiff leaves (Fig. 2a and b). Infection at the early tillering stage exhibited excessive dwarfing and tillering (Fig. 2c). When infected at the elongation stage, plants developed small spikes with barren grains and grain weight was low (Fig. 2d). The infected leaves were quite short, dark green, and rigid. Moreover, ruffles could be seen on the surfaces of the upper leaves (Fig. 2e). After elongation, aerial rootlets appeared at nodes (Fig. 2f); small, streaked, black or white tumor-like protrusions (1-2 mm in size) appeared on the stems (Fig. 2g).

\section{Determination of SRBSDV transmission efficiency}

A comparison of the infected sample sequences and the known SRBSDV S7-1 sequence (accession number: KM576880) and SRBSDV S9-1 sequence (accession number: KJ476862.1) revealed that sequence identity was $99 \%$. The transmission efficiency of SRBSDV to rice plants via the bud-cutting method was calculated using the PCR results and the PCR electrophoresis diagram can be found in Additional file 1: Figure S1. As shown in Table 1, the SRBSDV transmission efficiency in infected rice seedlings via the bud-cutting method was $90.00 \%$, $91.67 \%$, and $88.89 \%$ in trials 1,2 , and 3 , respectively.

\section{Protein identification}

The SRBSDV P1, P2, P3, P4, P5-1, P5-2, P6, P8, P9-1, P9-2, and P10 proteins, with the confidence level values of $66 \%, 66 \%, 95 \%, 99 \%, 99 \%, 99 \%, 99 \%, 99 \%, 99 \%, 99 \%$, and $99 \%$, respectively (Table 2), were identified in the infected rice seedlings using a proteomics approach, which demonstrated that SRBSDV was successfully transmitted to rice plants via the bud-cutting method. The detailed data of the peptides hits to each protein was shown in Additional file 2.

\section{Discussion}

Researchers studying SRBSDV-insect vector-host plant interactions are frequently hampered by a lack of sufficient viral samples owing to the limited life span of the infected vectors and rice plants and the low virus acquisition and inoculation rate of the WBPH vector. Previous studies have reported that the minimum virus acquisition period ranges from 2 to $8 \mathrm{~min}[7,14]$, that an inoculation access period of $30 \mathrm{~min}$ is required for not only WBPH nymphs but also WBPH adults, and that the period of virus's circulative transmission ranges from 3 to 14 days. Furthermore, the major of infected individuals transmit virus during intermittent periods, which range between 2 and 6 days [7, 14]. Meanwhile, Li and coworkers reported that the transmission efficiencies of SRBSDV by macropterous and brachypterous WBPH adults from infected rice plants to healthy rice seedlings were $23.7 \%$ at $15{ }^{\circ} \mathrm{C}, 53.6 \%$ at $25{ }^{\circ} \mathrm{C}$, and $7.3 \%$ at $35{ }^{\circ} \mathrm{C}$ [8]. By contrast, the virus transmission abilities of SRBSDV in rice plants using the bud-cutting method 


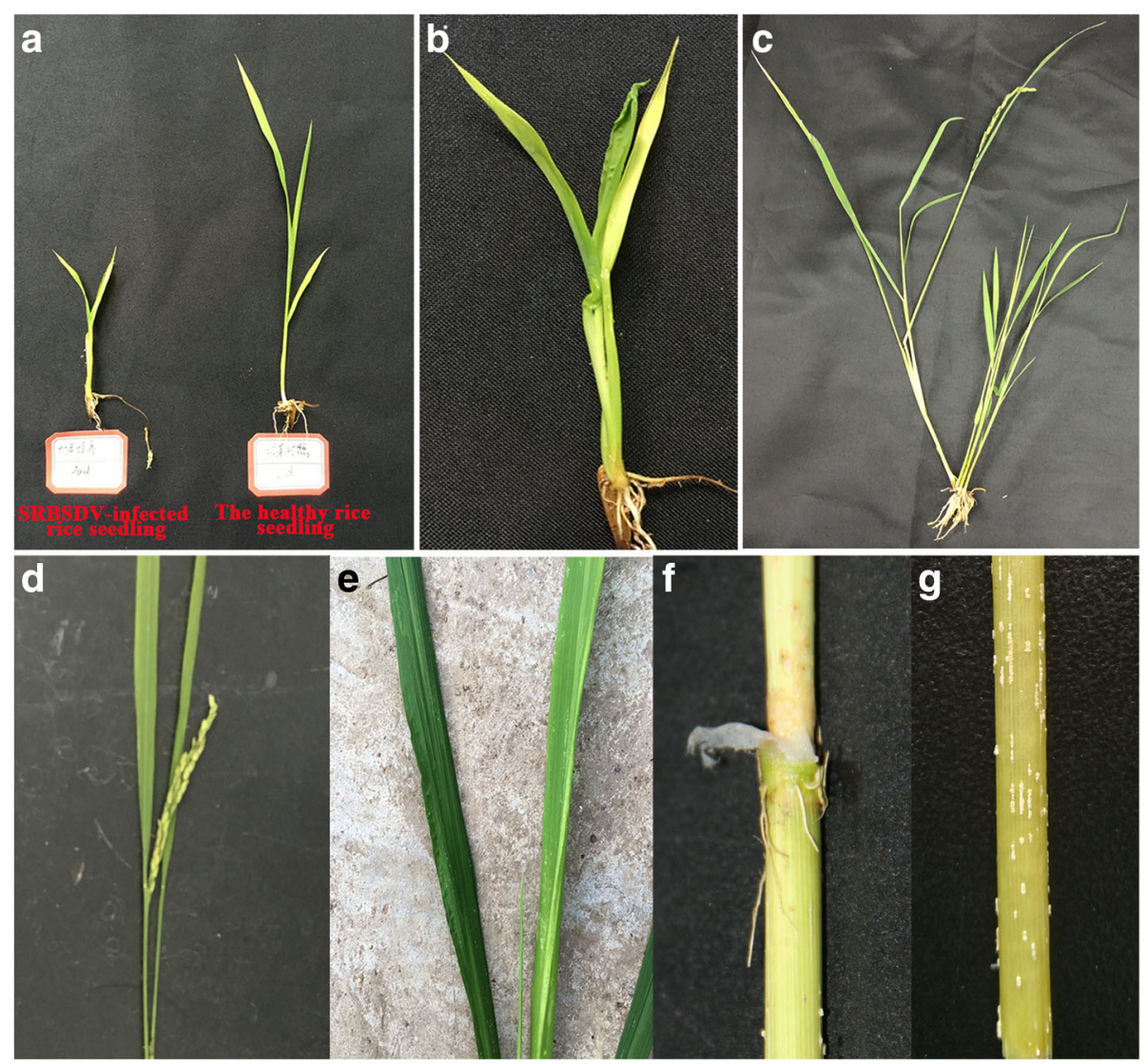

Fig. 2 Symptoms of SRBSDV disease in rice infected with SRBSDV using the bud-cutting method. a Infected seedling showing symptoms of dwarfism (left); uninfected seedling (right). $\mathbf{b}$ Infected seedling with stiff leaves. c Plant infected when tillering showing excessive dwarfing and tillering. $\mathbf{d}$ Plant infected at the elongation stage: although growth has not been stunted, the spikes are small with barren grains and low grain weight. e Leaves of a diseased plant: short, dark green, and rigid, with ruffles near the leaf base. $\mathbf{f}$ Aerial rootlets at the stem node. $\mathbf{g}$ Stem with small, streaked, white tumor-like protrusions $(1-2 \mathrm{~mm})$

were determined in detail in this study and the results were confirmed that the bud-cutting method was an efficient persistent-transmitting method with a shorter virus transmission time (30 $\mathrm{min})$ and a higher virus transmission rate (> 80.00\%).

The rice disease caused by SRBSDV produces symptoms similar to those induced by rice black-streaked dwarf virus (RBSDV) at different growth stages of the host. In this study, we obtained similar disease symptoms to those observed on rice plants infected with SRBSDV by the WBPH vector (Fig. 1). These symptoms can show as dwarfism and stiff leaves at the early

Table 1 SRBSDV transmission efficiency of the bud cutting method in rice seedlings

\begin{tabular}{llll}
\hline Trial & $\begin{array}{l}\text { No. of rice } \\
\text { seedlings tested }\end{array}$ & $\begin{array}{l}\text { No. of rice } \\
\text { seedlings infected }\end{array}$ & $\begin{array}{l}\text { Transmission } \\
\text { efficiency (\%) }\end{array}$ \\
\hline 1 & 10 & 9 & 90.00 \\
2 & 12 & 11 & 91.67 \\
3 & 9 & 8 & 88.89 \\
\hline
\end{tabular}

seedling stage; small spikes, barren grains, abnormally short and dark green leaves with ruffles at the elongation stage; aerial rootlets and branching at nodes, and small streaked waxy galls on stems, which agrees with the findings reported by previous studies $[1,11]$.

Some studies have indicated that SRBSDV is composed of icosahedral particles, consisting of 10 segments, which are defined as S1 to S10 based on size mainly ranging from 4.5 to $1.4 \mathrm{~kb}[2,12,22]$. When compared with RBSDV, SRBSDV encodes six putative structural proteins (P1, P2, P3, P4, P8, and P10) at least [23, 24], which respectively refer to a putative RNA-dependent RNA polymerase, a core protein, a putative capping enzyme, an outer-shell B-spike protein, a putative core protein, and a major outer capsid protein [25-29]. Moreover, SRBSDV encodes five putative nonstructural proteins (P6, P7-1, P7-2, P9-1, and P9-2), among which P6 refers to a viral RNA-silencing suppressor and tubules in nonhost insect cells [30]. Through forming intracellular viroplasms, P9-1 plays a necessary role in virus's early life [31]. Herein, we adopted a proteomics approach to 
Table 2 Identification of SRBSDV proteins in the viruliferous rice seedlings

\begin{tabular}{llllll}
\hline NO. & Protein ID & Protein name & Species & Unused & Conf. \\
\hline 1 & E4WKV7_9REOV & P1 protein & 9REOV & 0.53 & 66 \\
2 & J9UCP0_9REOV & P2 protein & 9REOV & 1.12 & 66 \\
3 & M4GP49_9REOV & P3 protein & 9REOV & 1.87 & 95 \\
4 & E4WKW7_9REOV & P4 protein & 9REOV & 4.18 & 99 \\
5 & J9UM56_9REOV & P5-1 protein & 9REOV & 2.51 & 99 \\
6 & H9BJU8_9REOV & P5-2 protein & 9REOV & 2.13 & 99 \\
7 & NOA5Y4_9REOV & P6 protein & 9REOV & 6.12 & 99 \\
8 & A0A024CLV9_9REOV & P8 protein & 9REOV & 2.36 & 99 \\
9 & A0A0C4W4C8_9REOV & P9-1 protein & 9REOV & 2.18 & 99 \\
10 & NOA4C0_9REOV & P9-2 protein & 9REOV & 2.04 & 99 \\
11 & GOZCH9_9REOV & P10 protein & 9REOV & 2.17 & 99 \\
\hline
\end{tabular}

identify the SRBSDV P1, P2, P3, P4, P5-1, P5-2, P6, P8, $\mathrm{P} 9-1, \mathrm{P} 9-2$, and $\mathrm{P} 10$ proteins in the infected rice seedlings, which further validated the successful transmission of SRBSDV using the bud-cutting method. Unfortunately, in our present study, SRBSDV P7-1 and P7-2 proteins failed to detect in the infected rice seedlings. The undetectable expression level of P7-1 and P7-2 proteins might result from lacking of the transmitting vector. SRBSDV P7-1 protein, a virus movement protein, was recently reported to induce the formation of tubular structures in insect cells and played a key role in virus transmission via the insect vector [32]. Interestingly, our previous work showed that SRBSDV P7-1 protein could be detected in rice plants infected SRBSDV via the insect vector [32]. By contrast, in this study, SRBSDV was successfully transmitted to rice plants without insect vector and, therefore, SRBSDV P7-1 protein could not be detected in the infected rice seedlings via the proteomics method. Meanwhile, RBSDV P7-2 protein and its counterparts were considered to be involved in virus multiplication in plants or viral pathogenicity on plants [33]. However, literature reported that SRBSDV P7-2 protein was failed to detect in either SRBSDV infected plants or insects over the past two decades [34]. The result was consistent with our present study result, in which SRBSDV P7-2 protein was not yet identified in SRBSDV-infected hosts.

\section{Conclusions}

Our findings showed that SRBSDV could be successfully transmitted from infected to healthy rice seedlings using the bud-cutting method and this method resulted in a shorter virus transmission time and a higher transmission efficiency than transmitted by the WBPH. The use of the bud-cutting method to generate a cheap, efficient, reliable supply of SRBSDV-infected rice seedlings should aid the development of disease control strategies. And this method also could provide a new idea for the other virus transmission in monocot.

\section{Additional files}

Additional file 1: Fig. S1. SRBSDV detection by the PCR method. (A) M: DL2000 maker, Lanes 1-10: The S9-1 gene in rice plants infected with SRBSDV using the bud-cutting method; (B) M: DL2000 maker, Lanes 1-12: The S9-1 gene in rice plants infected with SRBSDV using the bud-cutting method; (C) M: DL2000 maker, Lanes 1-9: The S7-1 gene in rice plants infected with SRBSDV using the bud-cutting method. (DOCX $275 \mathrm{~kb}$ )

Additional file 2: The detailed data of the peptides hits to each protein. (XLSX 1578 kb)

\section{Abbreviations \\ ACN: Acetonitrile; DTT: Dithiothreitol; ELISA: Enzyme-linked immunosorbent assay; FA: Formic acid; M-MLV: Moloney murine leukemia virus; \\ NCBI: National center for biotechnology information; PCR: Polymerase chain reaction; PCR-DGGE: PCR denaturing gradient gel electrophoresis; RRI: RNase inhibitor; RT-qPCR: Real time quantitative PCR; SRBSDV: Southern rice black-streaked dwarf virus; WBPH: White-backed planthopper}

\section{Acknowledgements}

We acknowledge the Collaborative Innovation Center for Natural Products and Biological Drugs of Yunnan.

\section{Funding}

This study was financially supported by the National Natural Science Foundation of China (Nos. 21,132,003 and 21,562,013) and Subsidy Project for Outstanding Key Laboratory of Guizhou Province in China (No. 20154004) and the Provincial University Cooperation Plan of Guizhou Province in China (No. 20147001).

\section{Availability of data and materials}

Raw data from shotgun data acquisition were deposited in iProx (http:// www.iprox.org) with accession number IPX0000954001.

\section{Open access}

This article is distributed under the terms of the Creative Commons Attribution 4.0 International License (http://creativecommons.org/licenses/by/ 4.0/), which permits unrestricted use, distribution, and reproduction in any medium, provided you give appropriate credit to the original author(s) and the source, provide a link to the Creative Commons license, and indicate if changes were made. The Creative Commons Public Domain Dedication waiver (http://creativecommons.org/publicdomain/zero/1.0/) applies to the data made available in this article, unless otherwise stated.

\section{Authors' contributions}

LY and BAS conceived and designed the experiments; LY, LLC, GPZ, WLW, and JS performed the experiments; LY analyzed the data; LY and DYH wrote the paper. All authors read and approved the final manuscript.

Ethics approval and consent to participate

Not applicable.

Consent for publication

Not applicable.

Competing interests

The authors declare that they have no competing interests.

\section{Publisher's Note}

Springer Nature remains neutral with regard to jurisdictional claims in published maps and institutional affiliations. 
Received: 4 April 2017 Accepted: 25 July 2017

\section{Published online: 15 August 2017}

\section{References}

1. Zhou GH, Xu DL, Xu DG, Zhang MX. Southern rice black-streaked dwarf virus: a white-backed planthopper-transmitted fijivirus threatening rice production in Asia. Front Microbiol. 2013;4:1-8.

2. Zhou GH, Wen JJ, Cai DJ, Li P, Xu DL, Zhang SG. Southern rice blackstreaked dwarf virus: a new proposed Fijivirus species in the family Reoviridae. Chin Sci Bull. 2008:53:3677-85.

3. Matsukura K, Towata T, Sakai J, Onuki M, Okuda M, Matsumura M. Dynamics of southern rice black-streaked dwarf virus in rice and implication for virus acquisition. Phytopathology. 2013;103:509-12.

4. Hoang AT, Zhang HM, Yang J, Chen JP, Hébrard E, Zhou GH, Vinh VN, Cheng JA. Identification, characterization, and distribution of southern rice black-streaked dwarf virus in Vietnam. Plant Dis. 2011;95:1063-9.

5. Liu WC, Liu Y, Guo R. Alert serious harm caused by the south rice blackstreaked dwarf disease outbreak. Chin Plant Prot. 2010;30:17-8.

6. Zhong TR, Liu Y, Liu WC. The causes and trends of southern rice blackstreaked dwarf virus occurred in China 2010. Chin Plant Prot. 2011:31:32-4.

7. Cao Y, Pan F, Zhou Q, Li GH, Liu SQ, Huang ZN, Li YZ. Transmission characteristics of Sogatella furcifera: a vector of the southern rice blackstreaked dwarf virus. Chin J Appl Entomol. 2011;48:1314-20.

8. Li YZ, Cao Y, Zhou Q, Guo HM, Ou GC. The efficiency of southern rice blackstreaked dwarf virus transmission by the vector Sogatella furcifera to different host plant species. J Integr Agr. 2012:11:621-7.

9. Li P, Li F, Han YQ, Yang L, Liao XL, Hou ML. Asymmetric spread of SRBSDV between rice and corn plants by the vector Sogatella furcifera (Hemiptera: Delphacidae). PLoS One. 2016;11:e0165014.

10. Guo R, Zhou GH, Zhang SG. Occurring regularity of southern rice blackstreaked dwarf virus disease and its controlling strategy. China Plant Prot. 2010;30:17-9.

11. Zhou GH, Zhang SG, Zou SF, Xu ZW, Zhou ZQ. Occurrence and damage analysis of a new rice dwarf disease caused by southern rice black-streaked dwarf virus. Crop Prot. 2010:36:144-6.

12. Wang ZC, Yu DD, Li XY, Zeng MJ, Chen Z, Bi L, Liu JJ, Jin LH, Hu DY, Yang S, Song BA. The development and application of a dot-ELISA assay for diagnosis of southern rice black-streaked dwarf disease in the field. Viruses. 2012;4:167-83.

13. Zhou T, Du LL, Fan YJ, Zhou YJ. Reverse transcriptionloop-mediated isothermal amplication of RNA for and rapid detection of southern rice black-streaked dwarf virus sensitive. J Virol Methods. 2012;180:91-5.

14. Pu LL, Xie GH, Ji CY, Ling B, Zhang MX, Xu DL, Zhou GH. Transmission characteristics of southern rice black-streaked dwarf virus by rice planthoppers. Crop Prot. 2012;41:71-6.

15. Yu DD, Wang ZC, Liu J, Lv MM, Liu JJ, Li XY, Chen Z, Jin LH, Hu DY, Yang S, Song BA. Screening anti-southern rice black-streaked dwarf virus drugs based on 57-1 gene expression in rice suspension cells. J Agric Food Chem. 2013:61:8049-55.

16. Wang Q, Yang J, Zhou GH, Zhang HW, Chen JP, Adams MJ. The complete genome sequence of two isolates of southern rice black-streaked dwarf virus, a new member of the genus Fijivirus. J Phytopathol. 2010;158:733-7.

17. Sengupta D, Kannan M, Reddy AR. A root proteomics-based insight reveals dynamic regulation of root proteins under progressive drought stress and recovery in Vigna radiata (L.) Wilczek. Planta. 2011;233:1111-27.

18. He DL, Han C, Yao JL, Shen SH, Yang PF. Constructing the metabolic and regulatory pathways in germinating rice seeds through proteomic approach. Proteomics. 2011;11:2693-713.

19. Chen Z, Guo Q, Chen BH, Li XY, Wang ZC, He P, Yan F, Hu DY, Yang S. Development of proteomic technology of shotgun and label free combined with multiple reaction monitoring to simultaneously detect southern rice black-streaked dwarf virus and rice ragged stunt virus. Virusdis. 2014;25:322-30

20. Cox J, Mann M. MaxQuant enables high peptide identification rates, individualized p.P.B.-range mass accuracies and proteome-wide protein quantification. Nat Biotechnol. 2008;26:1367-72.

21. Cox J, Neuhauser N, Michalski A, Scheltema RA, Olsen JV, Mann M. Andromeda: a peptide search engine integrated into the MaxQuant environment. J Proteome Res. 2011;10:1794-805.

22. Yin X, Xu FF, Zheng FQ, Li XD, Liu BS, Zhang CQ. Molecular characterization of segments $S 7$ to $S 10$ of a southern rice black-streaked dwarf virus isolate from maize in northern China. Virol Sin. 2011;26:47-3.
23. Wang ZC, Li XY, Wang WL, Zhang WY, Yu L, Hu DY, Song BA. Interaction research on the antiviral molecule Dufulin targeting on southern rice black streaked dwarf virus P9-1 nonstructural protein. Viruses. 2015;7:1454-73.

24. Jia DS, Chen HY, Mao QZ, Liu QF, Wei TY. Restriction of viral dissemination from the midgut determines incompetence of small brown planthopper as a vector of southern rice black-streaked dwarf virus. Virus Res. 2012;167:404-8.

25. Fereres A, Moreno A. Behavioural aspects influencing plant virus transmission by homopteran insects. Virus Res. 2009;141:158-68.

26. Zhang HM, Chen JP, Adams M. Molecular characterisation of segments 1 to 6 of rice black-streaked dwarf virus from China provides the complete genome. Arch Virol. 2001;146:2331-9.

27. Jia DS, Chen HY, Zheng AL, Chen Q, Liu QF, Xie LH, Wu Z, Wei TY. Development of an insect vector cell culture and RNA interference system to investigate the functional role of Fijivirus replication protein. J Virol. 2012;86:5800-7.

28. Isogai M, Uyeda I, Lee BC. Detection and assignment of proteins encoded by rice black streaked dwarf fijivirus S7, S8, S9 and S10. J Gen Virol. 1998;79: 1487-94.

29. Zhang HM, Chen JP, Lei $J$, Adams MJ. Sequence analysis shows that a dwarfing disease on rice, wheat and maize in China is caused by rice blackstreaked dwarf virus. Eur J Plant Pathol. 2001;107:563-7.

30. Lu YH, Zhang JF, Xiong RY, Xu QF, Zhou YJ. Identification of an RNA silencing suppressor encoded by southern rice black-streaked dwarf virus S6. Sci Agric Sin. 2011:44:2909-17.

31. Takumi S, Eiko NN, Fusamichi A, Tamaki UI, Toshihiro O, Takahide S. Immunity to rice black streaked dwarf virus, a plant reovirus, can be achieved in rice plants by RNA silencing against the gene for the viroplasm component protein. Virus Res. 2011;160:400-3.

32. Liu Y, Jiao DS, Chen HY, Chen Q, Xie LH, Wu ZJ, Wei TY. The P7-1 protein of southern rice black-streaked dwarf virus, a fijivirus, induces the formation of tubular structures in insect cells. Arch Virol. 2011;156:1729-36.

33. Mao QZ, Zheng SL, Han QM, Chen HY, Ma YY, Jia DS, Chen Q, Wei TY. New model for the genesis and maturation of viroplasms induced by fijiviruses in insect vector cells. J Virol. 2013:87:6819-28.

34. Wang Q, Tao T, Han YH, Chen XR, Fan ZF, Li DW, Yu JL, Han CG. Nonstructural protein P7-2 encoded by Rice black-streaked dwarf virus interacts with SKP1, a core subunit of SCF ubiquitin ligase. Virol J. 2013;10:325.

\section{Submit your next manuscript to BioMed Central and we will help you at every step:}

- We accept pre-submission inquiries

- Our selector tool helps you to find the most relevant journal

- We provide round the clock customer support

- Convenient online submission

- Thorough peer review

- Inclusion in PubMed and all major indexing services

- Maximum visibility for your research

Submit your manuscript at www.biomedcentral.com/submit
) Biomed Central 